\title{
When Academicians Mislead Readers
}

\section{David M. Buss: When Men Behave Badly: The Hidden Roots of Sexual Deception, Harassment, and Assault (New York: Little Brown Spark, 2021, 336 pp.)}

\section{Ferrel M. Christensen ${ }^{1}$ (10}

Accepted: 24 August 2021 / Published online: 20 September 2021

(c) The Author(s), under exclusive licence to Springer Science+Business Media, LLC, part of Springer Nature 2021

\section{Introduction}

The purported purpose of When Men Behave Badly is to reveal the evolutionary sources of sexual conflict between women and men. The book is evidently directed at the average reader, not at those already well familiar with evolutionary psychology. In any case it claims to present important new insights, as in its opening audacious sentence: "This book uncovers the hidden roots of sexual conflict". I will argue that most of what it "uncovers" is either [1] not new, or [2] just borrowed from certain ideologues, or [3] merely dogma endemic in our culture-and a great deal of it is false. As to [1], sexual evolutionary psychology has been researched and debated for half a century, beginning with Robert Trivers' (1972) pioneering essay "Parental investment and sexual selection", and the little "regular" psychology in the book is also already well known.

To begin, though the book is about evolution and sex, I submit that it is incomplete due to how little it says about love. (Not love in the "Christian" sense of warm good will toward others, but "romantic" attachment.) In the end it lauds the "deep psychology of love attachment", but that judgment (which sounds poetic rather than scientific) has not been discussed in the book. My best guess is that this emotion arose with Homo erectus, whose apparent predecessor, the small and small-brained Homo habilis, evidently got some of its food by scavenging the remains left by large carnivores. But $H$. erectus was much taller and had a much larger brain, hence may well have hunted its own prey (say, via running on its long legs, throwing rocks or wooden spears). In any case, a standard idea is that human ancestral offspring would have needed a much longer childhood to develop their much larger brain, and that this would have been greatly aided by having the father involved in childrearing

Ferrel M. Christensen

fchriste@ualberta.ca

1 Philosophy Department, University of Alberta, Edmonton, Canada 
as well, be it by providing nutritious meat or more hands-on caregiving, or both. Evidently, then, the genes that program the ancient neurohormonal love-bond between mother and child were activated in males, producing a capacity in them for love-bonding with both the mother and the child(ren). The extended families of both parents could also help with childrearing, another selective advantage. A seemingly related difference between humans and their great-ape cousins may be summarized in the following way: among the latter, females desire sex only during times when they are ovulating, which times are far apart, and in that brief period their bodies signal their fertility to males; but human females are capable of desiring sex at nearly any time, and their bodies send no signal to males when they ovulate"covert estrus". A common theory is that her near-constant capacity for having sex induces a mate to remain close to her-to the benefit of offspring and/or the prevention of cuckoldry.

Like most other human traits, love in this sense varies considerably from one individual to another, and also over time for each individual. So our culture's ideal of head-over-heels, lifetime-lasting feelings is just the rare extreme end of a complex distribution of feelings whose brain electrochemistry is far from understood. In fact, nature's statistical variation produces some individuals who are too independent to feel a need for a unique partner, as opposed to friendly interactions with many conspecifics. Further, sexual desire (lust) and romantic love both exhibit varying degrees and intermingled effects. Consequently, the book's division into long-term and short term "mating strategies" is dangerously simplistic. A student once told me that when he was in love with someone, he genuinely "only had eyes for her"-but when not in love, he was promiscuous. (As a technical term, 'promiscuous' does not mean 'anyone will do', merely that various potential sex-partners are found sufficiently attractive.) I see a need to discuss romantic love in its variations because it is the basic source of what the book calls "long-term" mating, whether it be from "love at first sight" or (notably in cultures with arranged marriages) developed over time. Also despite our society's myths, it too very often gives rise to conflicts between men and women. Notably, it is a key source of jealousy in both sexes, which the book decries often as a primary wellspring of conflict. And surveys have found that, to repeat, it rarely lasts a lifetime. Some lost-love couples remain together for the sake of the children, in others it is gradually replaced by a close friendship-and in others, for economic or societal reasons, they stay together and suffer it out. But in many other cases love ends in only one of the partners, often leaving the other with feelings of resentment or betrayal. Like so much of what blind evolution creates, the love-lust complex involves a mixture of bad aspects as well as good ones.

Now, since the religious conquest of most of the world by the Abrahamic religions, lust and romantic love have been widely viewed as morally very different: the former as worthy, but the latter as evil, requiring something "good" (love or marriage, usually) to "redeem" it. Beginning with a myth about a serpent convincing Adam and Eve that their genitals were shameful, the general view became that the flesh is evil, but love is "of the spirit". No such distinction is made by modern science. Both desires in themselves are morally neutral; they are just caused by different neurohormonal processes, and merely felt in different parts of the body. In older cultures and seemingly once in all humans, the common pattern is promiscuity among 
the unmarried-i.e., before any marriage and between marriages-and socially enforced monogamy among the married (some cultures allowing "infidelity" on special occasions, and some allowing polygyny in some circumstances). Consider two examples: the pygmy Mbuti—foragers-and the Trobriand Islanders-subsistence farmers. Each group was studied for years, the latter by Bronislaw Malinowski (1929) and the former by Colin Turnbull (1961). For example, Turnbull tells us that foraging expeditions by young unmarried Mbuti often resulted in orgies on the trail. And Malinowski reports that the typical age for girls to begin sexual intercourse with boys was six years (eight for boys). Dr. Buss's seeming habit of basing conclusions about humans through pre-history either on our own modern culture or on rare outliers such as the Tiwi and the Yanomamo, I would say, distorts his picture of natural human sexuality.

As a possible example, the book repeatedly says that females have less sexual desire than males, listing it as a source of conflict. This is assuredly true in our culture, but it may be that women's sexual desire is merely more flexible, to fit social or individual conditions, hence can be as strong as men's-either is compatible with sexual selection. Anthropologist Bengt Danielsson's euphemistically titled 'Love in the South Seas" (1956) is one good source of information about women's sexuality in earlier human cultures. Indeed, before Polynesia became so fully Christianized, it was a duty of aunts and uncles to teach sexual techniques to very young nieces and nephews, respectively, so that they would have a lifetime of sexual pleasure.

Though a brief personal anecdote can have little force, one of mine from the 1970's left a strong impression on me as regards cultural female sexual flexibility. As I entered a laundromat in Waikiki, my eyes were met by an admiring gaze from a young Polynesian (but facially not Hawaiian) woman. I could do nothing at that point but arrange my basket-load of clothing in the nearest available washer. When I stood up, she was standing casually at the next washer. To start a conversation, I asked where she was from, and her answer was Bora-Bora. When I continued the conversation by remarking that it would be an interesting place for me to visit, her response was that if I went, I would surely be raped by females because of my good looks. From her smiling demeanor and subsequent words, it quickly became clear that she didn't mean literal rape, merely an aggressive physical embrace that would not be continued if I was uncompliant-though compliance was anticipated in her culture. (I was washing my clothes as part of a rush through preparations for an imminent flight back to my university on the mainland, so I could not stop to ask her for more details, and I did not see her again.) One more illustration of societal variance in female sexual attitudes: Anthropologist Eleanor Leacock describes an Amerind culture in which the women's language and actions were as highly sexual as the men's. She quotes a Jesuit missionary who was shocked by so much sexual talk, saying "their language has the foul odor of the sewers."

Another omission from Buss's book that is crucial to the sexual issues he discusses is the debate among evolutionary psychologists on the origin of patriarchy, rule by older males. One school of thought is that humans began as warring patriarchal apes, and Buss's comments constantly indicate that he belongs to this school; patriarchy is the result of natural male nastiness. The other view claims that organized war and patriarchy developed only very recently in evolutionary time. But this 
book's author never even mentions this highly germane dispute; he just presents his own view to the reader as fact. Given all the negative consequences he draws about the nature of human males, I consider this omission highly dishonest. But here is some commentary from the latter school of thought, written for a study group by anthropologist Dr. Helga Vierich, whom I met when she taught at my university:

I have spent three years doing fieldwork in the Kalahari among a group of hunting and gathering San or Bushman people. Gender relations among these people do not involve male dominance. And although there is a division of labor, male work and its products are not more highly valued than female work and its products. They are simply complementary economic activities. Huntergatherers today represent a fraction of the world's people, but they are by no means unimportant. We humans were all once hunter-gatherers and it was at most 10,000 years ago that other forms of economy appeared on earth. These other economies were various forms of farming and herding which, for reasons I cannot go into here, gave rise to endless cycles of population explosion and warfare which have had an enormous impact on the relative value placed on men and women, men's work and women's work.... [Patriarchy develops] in response to the need to produce generation after generation of young men who will see it as only fitting and proper that "real men" are those who can, if called upon, be warriors who may be killed or kill other human beings....

An excellent though brief essay on this debate is anthropologist Richard Lee's 2014 "Hunter-gatherers on the best-seller list: Steven Pinker and the "Bellicose School's" treatment of forager violence". (Available for downloading just by googling its title.) He presents an account of both theories and names of their prominent adherents, proceeding to dispute the "bellicose school's" arguments and present the alternative. Note that a mere 10,000 years is generally too little time for significant biological evolution in humans. For an example of Buss's "bellicose" views, his book gives several pieces of (far from conclusive) evidence for war being used to obtain women. But its only stated dates for these events is "seven thousand to five thousand years ago" and "AD 1325", and its undated events are not plausibly older than 10,000 years, given the dates of human migrations. Yet he concludes from them that "In short, much evidence converges" on the conclusion that such events go back "for hundreds of thousands of years". [Emphasis mine.]

It must be noted how much patriarchal systems differ from one another. In some Islamic parts of the Middle East and east Africa, the level at which women are controlled is horrendous to this day; in some places they are forbidden to let their faces show in public. It is a sad testament to the power of tradition, especially religious, and in particular that with any connection to sex. A beautiful face seen by any men but her husband? Shocking! In our own culture, patriarchy has been far more benign, and now is-despite the book's constant dogmatic pronouncements-virtually gone. (Partly due to the invention of effective birth control and modern technology, which removes the need for men's greater average muscular strength, even in war. And domestic conveniences have freed women to have careers. They no longer have to churn butter, etc., etc.) Also very significant is Western patriarchy's traditional chivalrous protectiveness toward women, which has long been to the disadvantage of 
ordinary men. Notably, being sent off on pain of great punishment to get their bodies and minds blown apart in war to protect the "women and children" safe at homerecall Dr. Vierich's key point. Yes, the heights of power are still mostly occupied by men, but so are the much larger lower levels of society. The book frequently equates the patriarchy of some very different cultures to our own. Beware "black-and-white" thinking when discussing very different cultures.

A large part of the book is focused on physical partner aggression (sexual abuse is discussed separately), which it blithely attributes to patriarchal control. But its discussion is seriously biased in various ways. There have been literally hundreds of sociological surveys asking people anonymously what they have done and suffered in this regard, beginning with the work of eminent sociologists Straus, Gelles and Steinmetz in the 1970s - which found statistical equality of such aggression between women and men, by women's own admission Straus et al., (1980). Literally hundreds of similar surveys have been conducted since then, getting basically that same result and expanding on it. (Until he burned out from the work of keeping track of all these "equal results" studies, a certain sociologist was keeping an annotated bibliography of them (Fiebert, 2012: http://www.csulb.edu/ mfiebert/assault.htm). And as the research questionnaires were improved to include such things as motives, it was found that more women initiate violence-they are not acting in retaliation or self-defence. Because of their lesser strength, the harm inflicted is expectably more often to women. In John Archer's (2000) large meta-analysis it is reported that " $62 \%$ of those injured by a partner were women". But being merely less able to inflict harm is not a moral virtue; the moral issues are motive and intent. One indicator of the harm that would be done, were women equally able, is the various survey-studies on psychological partner abuse: they too have found that both the amount of this abuse and of the resulting emotional suffering tend to be equal for men and women.

As for other sources of information on intimate-partner violence rates such as police statistics, Dr. Buss admits police bias against men, which has revealed itself in more than one study. In my locality, lawyer Grant Brown (2004) got permission to examine all the original partner-violence police reports for a given period, with their judicial results, finding huge discrimination against males. And a public survey reported in Gelles and Straus (1988), p. 262, found that police did nothing at all for abused men who called in for help-none of the things (arresting him, etc.) that they did for women.

If the reader has not heard any of this information before, the reason is that it has been widely suppressed-in public sources and even in some academic ones. (Years back, Dr. Straus reported already knowing of thirty studies of both genders that reported only the violence to women that they found.) Dr. Buss's book comes close to suppressing it. It alludes briefly to the groundbreaking study, but not to it or any of the countless others by name, saying simply that "This research was ignored for many years by scholars". That description sounds almost innocent. But it is not what happened. In the words of Richard Gelles (1999):

... my colleagues Murray Straus and Suzanne Steinmetz and I conducted the First National Family Violence Survey in 1976. The survey interviewed a nationally representative sample of 2143 individual family members. The 
results were reported in a number of scholarly articles and, finally, in the book Behind Closed Doors: Violence in the American Family. The most controversial finding, as it turned out, was that the rate of female-to-male intimate violence was the same as the rate of male-to-female violence. ... When my colleague Murray Straus presented these findings in 1977 at a conference on the subject of battered women, he was nearly hooted and booed from the stage. [Our findings] not only produced heated scholarly criticism, but intense and long-lasting personal attacks. All three of us received death threats. Bomb threats were phoned in to conference centers and buildings where we were scheduled to speak. Suzanne received the brunt of the attacks-individuals wrote and called her university urging that she be denied tenure; calls were made and letters were written to government agencies urging that her grant funding be rescinded. All three of us became "nonpersons" among domestic violence advocates. Invitations to conferences dwindled and dried up. Librarians publicly stated they would not order or shelve our books.... [Too many scholars got involved for this to last, and eventually Dr. Straus was putting on well-attended annual conferences studying violence in the family.]

Sociology is not a rigorous science, and I cannot here address the possible sources of error in all these studies. But my point in writing a book review is to assess, not any final truths, but the author's accuracy and honesty regarding the current state of the evidence. Of course, not all those hooting ideologues Gelles mentions were academics; but all wanted to believe that only or virtually only men are violent in the home, scientific evidence be damned. On a recent note, the book's biased reasoning that the Covid pandemic would put more women at risk of violence-trapped at home with an oppressor-has been roundly refuted by five official reports. (Coalition to End Domestic Violence, 2021): < http://endtodv.org/coron avirus-abuse-hoax/.

The relevance of this topic, intimate partner violence, to the book lies in the idea that men use it to control women. But the finding of equal commission of marital violence by men and women in our culture vitiates the book's claim that men in general want to exert full "patriarchal" control over their partners. Various surveys have addressed this specific claim-concluding strongly that men in our society have no more such desire for partner control than do women. One of them, as it turns out, is cited in Buss's own book-and revealingly (p. 136), his gender-neutral wording bypasses the issue of male control or violence. Yet from the cited article's abstract: "We found, contrary to some previous evolutionary assumptions, that men and women showed similar degrees of controlling behavior, and that this predicted physical aggression to partners in both sexes," and "men and women who had lower mate values showed more controlling behavior and (to a lesser extent) more physical aggression". (By two of the UK's most eminent family-violence researchers, Nicola Graham-Kevan and John Archer, 2009). Stets (1991) had reached the same equaluse-of-aggression-to-control result in a survey that she had conducted some years earlier.

The book recognizes early on the importance of information about homosexual relationships in regard to intimate partner violence (since the "patriarchal" desire for 
control would not seem to apply there), and says (p. 6) "There is a critical need for research to fill this gap." Yet there has been some credible research which it does not report. The most prominent one (Lie, G. et al. 1991) described a survey of 350 lesbians, $78 \%$ of whom had prior heterosexual and prior lesbian relationships. Reported abuse victimization for both:

\begin{tabular}{lll}
\hline & By male partner & By female partner \\
\hline Physical abuse & $34 \%$ & $45 \%$ \\
Sexual abuse & $42 \%$ & $52 \%$ \\
Verbal abuse & $55 \%$ & $65 \%$ \\
\hline
\end{tabular}

It is crucially important to point out the real-life consequences of the anti-male stereotyping regarding partner violence. The bias it leads to in the legal system has already been mentioned, but a tragic kind I know well from my post-retirement activist work is lying about such violence in divorce court. I have literally seen men who came to our local parenting-equality group for help driven to insanity and suicide by this bias. (Both sexes were given what help our volunteers could, but fathers are far more often ripped out of their children's lives by judges.) Recall Jeanette Harris, the juror dismissed during the O. J. Simpson trial for initially telling that court she had not been an abused wife-yet records proved she had made that claim during her divorce. Her defense was, in effect, "But of course I said then that I'd been abused; after all, I was getting a divorce!".

Much of the highly relevant information left out of the book may be from honest ignorance - though one who claims to be presenting the available evidence on a topic should be thorough. Unfortunately, some of the book's omissions seem impossible to excuse. Consider the notorious case of Karla Homolka, whom the book describes merely as having married a serial rapist, one who "continued his raping spree" despite her being "an attractive woman". Not mentioned is the fact that she joined his activities, luring and kidnapping young women. And the fact that after they joined forces, their victims, including Karla's own sister, were murdered. (By himself, he had murdered no one.) Part of what was so scandalous was that the prosecution believed her story about just being a battered wife, letting her off the hookbut then videotapes surfaced revealing that she was fully involved in the rapes and kidnappings - indeed, she may have been the sole murderer. It is hard to believe that wherever Dr. Buss got his information about this case, these lurid facts, and many others, were not told there.

Now, many passages in this book are written gender-inclusively, and a few anecdotes of female wrongdoing are told. But it is never very long before it returns to its anti-male generalizing. Often it damns men with faint praise, saying things with the structure "Not all men [my emphasis] do rotten thing X" But a singularly revealing example of Buss's attitudes is his mention of Susan Brownmiller's infamous book Against Our Will. Buss quotes her book's central thesis that rape is "a conscious process of intimidation by which all men [that includes you, David Buss] keep all women in a state of fear". He does not include the rest of her claim, namely that 
even non-rapists secretly cheer rapists on in order to keep women in their firm control. Were any such horrible desire attributed to any societal category but men, it would be universally recognized for what it is: vicious lying bigotry. But his qualification is hardly better: Very late in the book he casually says, "Despite occasional declarations to the contrary, not all men are rapists or even potential rapists." (Compare "Not all blacks are pimps and drug-dealers".) That is so generous of you, Dr. Buss.

Instead of denouncing her bigotry, at this point the book just turns casually to the question of "whether or not [my emphasis - this query at least replaces Brownmiller's dogma with a hypothesis to be tested] there exist universal features of men's sexual psychology that are designed [by Darwinian selection] specifically for forced sex." Without that word'specifically', this question would seem to violate Occam's Razor: Men are programmed with a strong desire for sex; and under appropriate conditions, humans can do horrible things to fulfil desires. (Those Hutu nuns who participated in the Tutsi genocide come to mind.) For rape, nothing more specific than willingness to do horrid things in general would be needed-any more than, say, robbery or other violent crimes. Only extremists like Brownmiller, who blame all men for what some men do, would think otherwise. Indeed, this would appear to be related to her claim that rape is motivated solely by a desire to exercise power, not desire for sex. (As if a man could have an erection without being sexually arousedit can happen, but extremely rarely.) The book does argue that no one specific trait has evolved to make men rapists. But later, we shall see, it does claim-illogicallythat some special evolved sexual traits can contribute to rape.

Instead of causes, the book first looks for signs of a tendency to rape. One of its topics is rape-fantasies - which reveals that for a psychologist, Buss may not understand the roles of fantasy very well. Many people have fantasies of things that they would never dream of doing in real life. (Maybe he never played cops-and-robbers as a child.) Nancy Friday's (1973) book My Secret Garden reported that the largest category of sexual fantasies women sent to her was that of being raped (but not viciously). A motivating feeling could be "Oh, joy-he desires me so much that he can't control himself!" Also, the excitement of fear can enhance sexual excitement, even just in imagination. Beyond fantasy, it has long been reported that the bestselling category of women's literature is the "bodice-ripper". In fact, though I know of no surveys on the topic, some men's fantasies include being forced to have sex by a beautiful woman. Whatever is the whole nature of fantasies, their existence cannot be used for evidence of real desires, much less real actions.

Another type of evidence of built-in desire to rape the book proposes is the world's history of rape in warfare. But considering the general nature of war, this is in the same category as wartime looting - again not different from illicitly acquiring anything else one might want, when circumstances permit. And certainly not the sort of thing to throw light on ordinary conflicts between ordinary women and men over sex. (Later the book talks about Brownmiller's "findings" regarding rape in war, as if she deserved discovery-credit for merely gathering together, in the service of her hate-mongering, information long known to anyone familiar with the history of war.) 
Another of the book's topics is survey evidence of the prevalence of rape. It reports that by avoiding the off-putting word 'rape' but describing actions that amount to the same thing ("Have you ever had sexual intercourse with an adult when they didn't want to because you used or threatened to use physical force?"), confessions of completed or attempted rape were elicited from $6.4 \%$ of a sample of male college students. It does not mention, though its cited source tells, that $80.8 \%$ of that $6.4 \%$ involved intoxication, a notorious disinhibitor-leaving a remainder of $1.2 \%$ who completed or attempted rape not so involved. But such numbers suggest that the great majority of young men-though still too manydo not do such things, even intoxicated.

The subject of rape is highly politicized, and competing claims of its incidence or prevalence cover a huge range. And they lead the over-zealous to "lying with statistics". Notably, certain surveys in use were created by people so anxious to maximize the numbers of raped women that their questions are loosened up regarding what counts as sexual assault. One blatant example is of the ilk "using constant pressure to achieve compliance" (nagging). But the tactic has backfired-such definitions have not infrequently made it look as if ordinary men are raped as much as or more than women. Consider these results from the National Center for Injury Prevention and Control (2011):

Women Completed forced penetration in last 12 months: $0.5 \%$ [NISVS table 2.1].

Men Made to penetrate in past 12 months: 1.1\% [NISVS table 2.2].

Whatever the rates of rape in various places and circumstances, they are not this book's topic, which is claimed to reveal the "hidden roots" (i. e., evolutionary causes) of sexual wrongdoing.

To set the stage for further explaining what is wrong with many of the book's claims, let me relate a crucial aspect of the evolution of human sexuality. (Dr. Buss would know this, but a large majority in our culture have never heard of it.) Among many mammals, sexual arousal in males is produced by special odors emitted by females in heat. But among the highly visual higher primates, the sole or primary source of such arousal is visual. To be precise, a hairless area of skin (the "sex skin") next to the vaginal opening becomes engorged and enlarges greatly during a female's fertile time. The sight of this strongly stimulates males' sexual desire. And the females will if necessary seek out one or more males and display her state to arouse them. To repeat, human females have no such visible changes during estrus, but they can still signal sexual desire to an attractive male by orienting their bodies so as to reveal their vaginal opening, and surely would have done so during evolutionary time. They, like males, also developed buttocks (apes don't have buttocks) due to the much larger muscles required for upright locomotion, and their hips had to widen to accommodate passage during birth of the larger-brained hominin babies - together a key part of the "hourglass figure". The other relevant visible change was the development of breasts, generally much larger than needed for lactation and now having sexual nerve-endings. The fact that breasts were always visible (humans evolved naked, though they no longer had much bodily hair) has made 
some wonder whether breasts' power to sexually attract is intrinsic. But faces too were always visible; it is what a female does with either, if they are always visible, that can give them that power. For one illustration, Colin Turnbull tells an anecdote about a young Mbuti woman with large breasts who deliberately danced in a way that made them bounce-and the immediate male attention that resulted.

All this changed when sexual shame and disgust were invented, in particular shame over others seeing one's own sexual organs. I earlier mentioned the spreading of these feelings by certain religions, and a good example of that is well known from the Euroamerican discovery of the Polynesian Islands. At first, when whaling ships would come to the islands, young Polynesian women would swim naked to the ships (Polynesians did not have bathing suits), often having sex right there on the decks. But as these peoples became mostly Christianized, they adopted the same sexual shame-with its negative affect on sexual enjoyment. Dr. Milton Diamond, who ran the Pacific Center for Sex and Society at the University of Hawaii, once wrote of interviewing a very old Hawaiian woman who expressed deep regrets at the considerable loss of sexual pleasure that followed. He also had a (caucasian) graduate student who had begun sexual intercourse at a very early age, who told me she could have an orgasm almost immediately upon penetration. It occurred to me that the reason so many women in Western culture have difficulty with sexual pleasure is the lack of natural sexual learning that followed sexual shame.

However this may be, I know certain things from my own experiences growing up. I absorbed the shame of anyone seeing my genitals. But by the age of seven, discussion with boys in my neighborhood revealed that they shared my craving to look at female genitals. (Not until years later, when we went through puberty, did we develop attraction to female breasts and other curves-which, hardly coincidentally, develop during female puberty.) As for the girls around that young age, they fell into two camps. A few were hot-to-trot at the idea of "playing doctor", whereas most were shocked and scornful. It seems clear that, for whatever reasons, some individuals are less prone to being influenced by sexual shame-conditioning. I myself was too fearful of the hatred aimed at males for their visual sexuality to participate (though a couple of young girls, on one occasion each, "flashed" me pantie-lessseemingly retaining their evolved tendencies). Nancy Friday's (1980) book Men in Love, in which she reported the feelings of men who were boys in that period of time (just prior to the "sexual revolution"), is very insightful about how they were affected by this culture's shame-teaching. She describes such a young boy, "angry and forlorn in the knowledge that [his visual sexual desires] are unacceptable to women. ...Women have placed his body at war with his soul. Only when he gets out of the house, only when he discovers that other little boys are just like himself, does he get enough reinforcement to bear being bad...." Of course, it isn't modern women's fault any more than modern men's - the problem is historical, together with the massive power of indoctrination and conditioning over humans in general. But if Dr. Buss genuinely desired to cure sexual conflict between males and females, he would recommend the ending of bodily shame. He assuredly does not.

In the 1980s, this perverse attitude led to a battle over visual pornography (the Meese-Commission days). By this point the feminist organization NOW had been taken over by those I label "sexist feminists" (their concern is women's self-interest, 
not equality) to distinguish them from original Second-Wave egalitarian feminists such as former NOW presidents Betty Friedan and Karen DeCrow. Joining forces with traditional Christians, the sexist feminists-such as Gloria Steinem and Catharine MacKinnon-went on a tear against male visual sexual feelings. But they were countered by egalitarian feminists ("pro-sex" feminists, they called themselves) such as Betty Dodson, Suzy Bright and Pat Califia, who could point out that - as I explained above-natural female sexual feelings are complementary to male attraction. (Some even produced their own porn magazines, such as On Our Backs).

Of course, a related aspect of our culture has been the endless battle over how revealing women's clothing should be near to their sexually arousing body parts. (Which, as I noted earlier, includes their faces in a few benighted cultures.) As one skimpy T-shirt puts it, "I dress this way because I WANT them to look". This is necessarily a long story; I tell some of it in my academic book Pornography: The Other Side (Christensen 1990a; still in print via Amazon Books). For a much shorter read, one whose topic is the illegitimate tactics some scientists use to ideological ends, one might see my article (Christensen, 1990a,1990b), which documents such bias in a few scientists.

In its section labeled The Curse of Sexual Coercion, the book (pp. 204-205) lists some male traits he sees as threatening male sexual coercion, the first four of them visual in nature. Yet as has been explained in my paragraphs above, the visual aspect is fundamental to human sexual attraction for both sexes-as the book admits elsewhere. (Though except for the face, it is other features of male bodies that females tend to find attractive. Only a very small percentage of women are aroused by the sight of a penis, which would serve no evolutionary purpose.) As an aside to reveal a personal source of my knowledge of this subject, for most of my life I have had the pleasurable experience of getting admiring looks from time to time-some of them extended, longing looks clearly intended to entice my interest-from women or girls who (since they were cases of "first sight") knew nothing about me but my appearance. Yet this list, and indeed the whole book, finds excuses to condemn male visual attraction to females-but never female visual attraction to males-and doesn't seem to notice that faces are visual.

As can be seen from rape statistics, young attractive women are indeed more likely to be raped. But is beauty a bad thing? Hardly. And given the visual nature of male sexuality, without it not only would there be no rape, there would be no human sex at all, indeed no humans. I submit that the real moral point is not the visual attraction, but that what is to be blamed is whatever tendencies make individuals willing to do harm to get what they want.

The list's fifth point, "men's high sex drive", faces the same conundrum, since no one would try to get, by coercion or cooperation, anything for which she or he had no desire. The book might as well say that the cause of theft is the existence of highly desirable things. But to repeat, the moral issue does not impugn the desired things themselves, only whatever influences might lead to the use of illegitimate means to obtain them. The list's sixth point speaks of "men's desire for sexual variety...even when [they] have existing sexual partners". Consider the analogy of a desire for a variety of friends, even when one already has one friend. I urge that this reveals the moral (not biological, obviously, for most humans) arbitrariness of 
sexual exclusivity. But what is relevant at this point is that the book provides no evidence for the claim that either desire in itself leads or would lead to coercion.

The list's next two claims involve two related traits: a "short-term mating strategy", and sex without emotional attachment. As to the latter, remember that romantic love itself produces dangers of physical violence by both genders, notably via jealousyarising out of fear of cuckoldry (in males) or of abandonment (in females). Indeed, in some monogamous species, a cuckolded male will himself rape his mate, presumably a way of possibly displacing the alien sperm. But the list provides no mechanism by which "short-term mating" in humans might lead to sexual coercion. Moreover, such a claim is strange because as noted earlier, the evidence indicates that virtually all humans, of both genders, are inherently capable of this "strategy" -indeed that it is a part or parts of the life-cycle, in many cultures (if not in all, originally). As close as this point gets to an argument is its tendentious use of the pejorative term impersonal', which hints that short-term sex cannot be friendly and mutually joyful, as can so many other human interactions - this is just another old canard.

As for the next point, "sexual over-perception bias", by the book's own description of this phenomenon, the clueless sap thinks she wants romance or consensual sex with him, not rape-and should be set straight as soon as he asks for a date. (As a male I have experienced only its female counterpart, taking my friendliness to indicate a romantic or sexual interest in them. The book talks as if such wishful thinking is solely a trait of males - and that it is extremely common. This has certainly not been true in my long experience observing male-female interactions.) The only claimed connection to coercion that I can see is the book's insinuation that rejected first-approach men commonly go into a rage-but nowhere is it supported by evidence.

The next point rests on "a link...between power and sex" that the book admits affects [only some, I insist] men and women both. But it makes no sense as a motive for coercion. If the purpose of acquiring power is to impress women, having to resort to coercion would be to admit failure. I see this point as confusing that special cause of sexual interest in some women, and the corresponding desire in some men to seek high status hence power of some kind, with the abuse of power, however obtained, per se. But also, as always, Dr. Buss sees only the male side of a behavioral dyad as bad. I have made the acquaintance of a woman who used to work for a Hollywood studio, and she complains bitterly about the women seeking a part in a movie who used a certain code-phrase on their application to indicate willingness to trade sex for it - hardly fair to other aspiring actresses-but revealing regarding the one-sidedness of so much sex-and-power discourse.

The rest of p. 205, more or less, describes the actual (and common-sensical) moral failings that can clearly lead to sexual coercion-and to coercive crimes of any other kind: a selfish lack of caring about harm to others. It makes this more precise using certain psychological traits- the Dark Triad, in today's accepted psychological categories. But as I said in my Introduction, there is no special insight in this commonsense idea that would justify claiming new knowledge about sexual conflicts. The same wrongful tendencies that lead some men to sexually harm women lead them to commit other harms to men-they are not specific to matters of sex. 
The following page makes a seeming addition when it speaks of "the Dark Triad and a strategy of casual sex that combine to make some men much more likely to be sexual coercers." But given everything else the book says about this "combination" (almost nothing, and certainly no data), the reason he gives is that the former facilitates the latter: p. 83 says that "Dark Triad" males make themselves more physically attractive, which "enables" them to "more successfully implement a short-term mating strategy". But how would being more successful without coercion make such men more likely to also be coercers? And even in the absence of any efforts to improve their appearance, p.56 says that women tend to find Dark Triad men more sexually appealing than other men-raising the same question. In either case, the Dark Triad feature and success at short-term mating are not a "combination" of independent causal factors: the latter is alleged by the book to be merely a causal consequence of the former. So even if it should be true, this coercion-claim does not fault short-term mating in itself, any more than it does the included consequence of engaging in sex per se.

And the final point in the list is itself a moral outrage: it alleges "The general willingness of men to use violence or threats of violence...." Dr. Buss presumably excepts himself (or maybe he is projecting?), but there is a word for this: bigotry. The fact that bigotry against men is so widely accepted in our society has a variety of historical and general sources. But anti-male bigotry by men has itself a sexualselection source: intra-gender competition. One of the oldest male gender roles is bashing other men (physically or verbally) to get the approval of women. But I suggest that genuinely egalitarian, moral women will not be impressed by this dishonest attempt to impress them; only those women who are already themselves anti-male bigots will welcome it. Whatever his actual illegitimate motives, I believe my revelations in this review repeatedly reveal that he has illegitimate motives.

The next-to-last chapter in the book contains one section, "The many harms of rape", with which I am certainly in agreement. Let no one suppose from my criticism of the book's deceptions and illogic that I am condoning sexual mistreatment, of women or men. There is no cause so noble that it cannot attract ignoble supporters. I have known a number of women who have been raped by strangers, and it is a horrible experience. And until recent years, the seriousness of rape had indeed not been at all adequately recognized. Outside of prisons and war, where anal rape of men is common, rape is rare for men to experience. This leads us to a point noted by (but hardly original to) this section: that any harm or danger faced by one gender but not by the other is harder for the latter to understand-hence educating men to the horrors of rape is essential to enhancing understanding between men and women. Essential, but nowhere near a full cure. Virtually all of our children are taught not to harm others, yet serious crimes-both violent and more subtle-continue. Our society is no more a "rape culture" than it is a "robbery-and-assault" culture, despite the pronouncements of certain extremists. And since the beginning of feminism's "Second Wave", numerous studies have revealed that as women have achieved more freedom and positions of power, crime by females has increased greatly.

Further, the difficulty of one gender understanding the other cuts both ways. Many women seem unaware of the harm to a male - from loss of his career to prison-of false claims of sexual wrongdoing. It has not, for example, been very long since the Rolling Stone debacle. When finally the accuser was exposed as having lied, the 
reason she gave for so doing was trivial-she had no concept of the harm she was doing, or didn't care. And the reporter who broke the story had made no attempt to check any of the accuser's claimed facts before going to print. So she additionally did not care about journalistic integrity, at least when the topic is a woman accusing a man. The truth was finally revealed by principled journalists-but only after much harm had been done. The Buss book itself never discusses false allegations of rape, much less admits the need for teaching females about harms to men of such allegations by women. Yet there have been many similar stories in recent years (see https://titleixforall.com/ for a current systematic collection of legal cases involving alleged examples.) This omission speaks yet again to the insincerity of Dr. Buss's professed desire for greater understanding between men and women involving sex.

The final chapter of this book, as one would expect, is a summary and partial expatiation of what has gone before. And its hate-filled deceit and sophistry reach a fever pitch. Its thesis is not the entirely arguable one that many of the conflicts between women and men arise because of their average trait-differences, but because women's behavior is good and men's is bad. But the matter is not hopeless, it says, because men can change, or be forced to change: "Men have the capacity for deception, but also the capacity for honest courtship",etc.,etc.

But one topic of this last chapter is of special importance: what it calls the sexual "objectification" of women (p. 267). This pejorative terminology began with the sexist feminists in the 1970's, as I recall, and its etymological import arises from male visual attraction to women's bodies, which are objects. (The canine counterpart would be 'aromafication'. Consider how horrible that is!) And in that original pejorative usage, it was nothing but a reaction to the shame associated with the naked body in our culture. The term evolved, however, to express a claim of men as viewing, or else valuing, women as nothing but sexual entities. I began this review by saying that the book contains little new of any consequence-and that includes its irrational arguments. It adopts wholesale the objectification rhetoric of the 1980's (and continuing) anti-male feminists.

It starts with the claim "That men sexualize women, notice their physical appearance before many other attributes, and sometimes view women as sex objects are observations so obvious that pointing them out evokes reactions similar to noting that water is wet". Remarks of this sort- "It is obvious that..." are often made by people who know they are merely spouting unsupported dogma, perhaps even meaningless cant. As a biological fact, women are already sexual, and cannot be given a trait they already have. As for what is noticed first about anyone, since the great majority of first encounters (in person or videonically) are by sight, the second phrase here is a virtual tautology. Third, a typical object has no sexuality, so the only way to literally treat women as objects is to pretend they are non-sexual. Note also that remarks parallel to these three could equally well — hence equally irrationally-be made about women regarding men, which is yet another clear signal of the book's bigotry.

Since these rhetorical phrases are nonsensical, let me turn to what I noted above as their literal intent: that women in general, or some particular woman, are seen as having no other traits than their sexuality, or that the accused men don't care about women's other traits, especially the admirable ones. The first surely is just impossible: how could anyone blot out of his or her consciousness what is known from long 
experience about others of either gender? As for the second, consider various kinds of relationships that exist among individuals. Say, my years of teaching students. With few exceptions, I did not get to know them personally, hence could not know anything about their specific personal lives or traits. Does that mean that I saw them only as intellect-objects? That they saw me only as an intellect-object? In our highly specialized world, some people find a niche as porn-actors and some as pipe-fitters (or singers, and on and on and on), depending on their interests and qualifications; that someone interacts with them in a way that involves only one trait does not mean that she/he does not know, or does not care, that they have other traits, good and bad. The idea that men see women this way is the fundamental idea behind objectification-claims. And it is just a bigoted lie. It is a claim of reading others' minds, in a way that a psychologist of all people should know better than to pretend to domuch less to call it ridiculously obvious. Perhaps someday neuro-physics tools will develop to the point where what one knows or cares about another individual can be determined with precision that great, but no such tools exist now. Dr. Buss is, to repeat, merely parroting the hate-rhetoric of ideologues.

That some people use meaningless rhetoric suggests that they are trying desperately to find a rationalization for the real source of their antipathy-whether it is this society's sexual-shame socialization or a general hatred of males or whatever. One good source of evidence of this is the idiocy of standard anti-pornography argumentswhich this book employs by rote. It begins (p.270) with'Most pornography embodies the sexual objectification of women in the extreme.' But aside from pin-ups, most pornography portrays both men and women doing sexual things; how could this "objectify" or "sexualize" only women, not men? It goes on to 'For men, it creates distorted and unrealistic impressions of women's sexual psychology", thus "sets up wildly unrealistic expectations in men's minds." If anything in our society has that effect, it is the lack of factual sex education young people get in our culture. But beyond that, any ordinary viewer realizes that pornography is a wish-fulfillment genre, not documentary. The book provides no evidence for this allegation; indeed, I have noted indications in this review that Dr. Buss himself has distorted and unrealistic impressions of women's natural sexual psychology, basing his claims on our modern Western culture and ignoring still-ancestral-oriented societies where sexual shame is not taught to children from an early age. In particular, the "short term mating strategy", which he seems to feel is naturally aversive to women, is attested to as natural for them by many original observers, not merely by the anthropologists mentioned in this review.

The book's next objection to pornography is that it can "supplant efforts to attract women in real life." Again, no evidence that this actually happens is given. (Men whom women find unappealing surely do turn to porn and masturbation as a poor substitute for real sex, but that is as effect, not cause.) The following paragraph begins "The modern proliferation of porn consumption, in short, has escalated both conflict between the sexes and the harms of female-female competition." If it is including the hate-diatribes of anti-male feminists (both male and female), it has the cause and effect of that conflict reversed. And certainly learned sexual shame can contribute to conflict, but that too misidentifies the real cause. Indeed, back in the days of rentable VCR tapes, proprietors of such shops reported that their largest category of customers (this sort of counting is evidently no longer possible)—-more 
than unaccompanied men-was male/female couples, many of whom reported that watching porn together spiced up their flagging sex-lives; this is conflict? Finally, nowhere does the book say in what manner pornography might exacerbate femalefemale competition (like cosmetics, for example?), much less provide any evidence.

The rest of this section on "objectification" is equally irrational. It begins with a legitimate problem: for whatever reasons, some individuals fixate on one thing to the exclusion of others, to the point of obsession-compulsion. There is little in this world so good that it cannot be taken to bad extremes. A popular example these days is obsession with using the Internet, but everything from exercise to cleanliness have become extreme in some people, to the neglect of other important things. The example relevant here is of course female beauty - and that of males, notably physique. In both cases, evolutionary psychologists have long claimed, they provide signs relevant to the ability to successfully reproduce. And both involve attraction to bodily, including facial, appearance. But to make the point again, Dr. Buss and his tribe apply the sophistical word 'objectification', with its built-in "only" deceit, just to women. A classic example is blaming men's attraction to female beauty for such conditions as anorexia and bulimia — which is particularly ironic because those conditions both involve a pathological desire to be thin, and men in general prefer women who are (up to a point that differs from one man to another) voluptuous.

The following section in this final chapter decries the harms caused by unequal numbers of men and women in a social milieu. This type of imbalance has had horrid consequences in places such as India and China, owing to their historically extreme forms of patriarchy. But this section's only worry is the "sex ratio problem" in American universities (17\% more female students at his own). And despite the fact that universities are the training-ground of our society's elite ("patriarchy", indeed), Dr.Buss blithely sees females as the only victims of the lopsided ratio, not the lesser career opportunities for men. Indeed, some disadvantages he invents for women are bizarre. Example: "Women in these imbalanced mating markets sometimes feel compelled to drink alcohol...to lower their inhibitions for engaging in sex that they might feel is unwanted [hence grounds for sexual accusations!] during more sober moments." And ignoring the decades of "affirmative action" for women, he blames the imbalance on men, who "need to catch up to women who are jetting ahead of them...".

This chapter's, and the book's, concluding section is titled "Toward harmony between the sexes". Since the message of the book is overwhelmingly "man bad, woman his victim", a label that smacks of conciliation over a mutual "conflict" is hardly appropriate. The section concludes by continuing to promote as fact the arrant falsehood that the modern West is a "patriarchy" that "views women as property to be possessed", and repeats a few of the book's earlier libels, such as the "objectification" lie.

It would itself require a book to analyze and document all of this book's moral and intellectual failings. However, I see this review as capturing the basic ones.

Funding No funds, grants, or other support was received. 
Availability of Data and Material No new data are reported in this article.

Code Availability No code is provided in this article.

\section{Declarations}

Conflict of interest The author has no financial or proprietary interests in any material discussed in this article.

\section{References}

Archer, J. (2000). Sex differences in aggression between heterosexual partners. Psychological Bulletin, 126(5), 651-680.

Brown, G. (2004). Gender as a factor in the response of the law-enforcement system to violence against partners. Sexuality and Culture, 8(3-4), 3-139.

Christensen, F. M. (1990a). Cultural and ideological bias in pornography research. Philosophy of the Social Sciences, 20(3), 371-375.

Christensen, F. M. (1990b). Pornography: The other side. Praeger, New York.

Coalition to End Domestic Violence (2021). Corona virus hoax. <http://endtodv.org/coron avirus-abuse-hoax/.

Danielsson, B. (1956). Love in the South Seas. G. Allen and Unwin.

Fiebert, M. (2012). References examining assaults by women on their spouses or male partners: an annotated bibliography. http://www.csulb.edu/ mfiebert/assault.htm.

Friday, N. (1973). My secret garden. Trident.

Friday, N. (1980). Men in love. Delacorte.

Gelles, R. (1999). "The missing persons in domestic violence: male victims", The Women's Quarterly, Autumn.

Gelles, R., \& Straus, M. (1988). Intimate violence. Simon and Schuster.

Graham-Kevan, N., \& Archer, J. (2009). Control tactics and partner violence in heterosexual relationships. Evolution and Human Behavior, 30(6), 445-452.

Lee, R. (2014). Hunter-gatherers on the best-seller list: Steven Pinker and the "Bellicose School's" treatment of forager violence. Journal of Aggression, Conflict and Peace Research, 6(4), 216-228.

Lie, G., Schilit, R., Bush, J., Montague, M., \& Reyes, L. (1991). Lesbians in currently aggressive relationships: How frequently do they report aggressive past relationships? Violence and Victims, $6(2)$, 121-135.

Malinowski, B. (1929). The sexual life of savages in North-Western Melanesia. Halcyon House.

National Center for Injury Prevention and Control (2011). Intimate Partner and Sexual Violence Survey, 2010, Summary Report, Centers for Disease Control and Prevention, Atlanta.

Stets, J. (1991). Psychological aggression in dating relationships: The role of interpersonal control. Journal of Family Violence, 6(1), 97-114.

Straus, M., Gelles, R., \& Steinmetz, S. (1980). Behind closed doors: Violence in the American family. Doubleday.

Trivers, Robert (1972). "Parental investment and sexual selection". In Sexual Selection and the Descent of Man, ed. by Campbell, B., Aldine, Chicago.

Turnbull, C. (1961). The forest people. Chatto and Lindus.

Publisher's Note Springer Nature remains neutral with regard to jurisdictional claims in published maps and institutional affiliations. 